Mathematical Modelling and Analysis

Volume 4, 1999, PAGeS 18-25

(C) 1999 Technika

\title{
GLYCEMIA MONITORING: THE PROBLEM OF EXOGENOUS INSULIN INPUT
}

\author{
I. BASOV ${ }^{1}$, M. MEILŪNAS ${ }^{1,2}$, D. ŠVITRA ${ }^{1}$ \\ ${ }^{1}$ Klaipèda University \\ H. Manto 84, LT - 5800, Klaipeda, Lithuania \\ ${ }^{2}$ Vilnius Gediminas Technical University \\ Saulètekio 11, Vilnius \\ E-mail: renret@ip.ku.lt, mecislovas.meilunas@fm.vtu.lt
}

Received September 24, 1999

\begin{abstract}
We present the system of two nonlinear difference-differential equations with lag which is a mathematical model of self-regulation of sugar level in blood. We analyze the pathological case, i.e. describe the concrete patients glycemia self-regulation system and diet. The model helps to determine the dosage and tactics of the traditional insulinotherapy practicing discrete inputs of insulin into the organism with the help of injections.
\end{abstract}

\section{THE SIMPLEST MATHEMATICAL MODEL OF THE BLOOD SUGAR LEVEL REGULATION}

The normal sugar level in a healthy organism is not constant, but oscillating within limits, that guarantee optimal conditions of providing sugar to tissues and, first of all, to the nervous system [1,2]. A significant decrease of level of sugar in blood leads to serious hypoglycemical disorders, which reflect seriously on the state of the entire organism. A protracted increase of level of sugar in blood leads to the development of diabetes. Thus, the study of the mechanism of self - regulation of the sugar level in blood is one of the most important problem of medicine.

The principal controller of glycemia is insulin. It is secreted by $\beta$-cells of Langerhan's islets dependingly on the content of sugar in blood. The increased level of sugar in blood stimulates the production of insulin and its entering 
into blood plasma, which causes the decrease of sugar level in blood. The insufficient level of insulin in blood results is diabetes mellitus.

Insulin in blood can exist freely or in combination with proteins. The free insulin directly decrease sugar content, while the connected one acts only when freed from proteins. At present, it is possible to measure only gross amount of insulin in blood, so - called immunoreactive insulin (IRI). Research [3] shows that there are rhythmical oscillations of the level of insulin in blood and they are related to the oscillations of level of sugar.

Low - frequency oscillations were detected while measuring the level of sugar in blood at various times of a day, during which the samples of blood were taken several times. The derived results allow to conclude the presence of the day - night oscillations of level of sugar in blood with the period of 24 hours $[4,5]$.

This allows to interpret the self - regulation of sugar level in blood as "predator - prey" type interaction, where the predator is insulin, and the prey is sugar. In the paper [6] D. Švitra offered the mathematical model as system of the following two nonlinear difference-differential equations:

$$
\begin{aligned}
& \dot{I}(t)=r_{1}\left\{\frac{G(t)}{K_{G}}+a\left[1-\frac{G(t)}{K_{G}}\right]-\frac{I(t-h)}{K_{I}}\right\} I(t), \\
& \dot{G}(t)=r_{G}\left\{1+b+a\left[1-\frac{I(t)}{K_{I}}\right]-\frac{G(t)}{K_{G}}\right\} G(t) .
\end{aligned}
$$

Here $I(t)$ is the level of insulin in plasma corresponding to the time moment $t$ and $K_{I}$ is its mean; $G(t)$ is the level of blood sugar and $K_{G}$ is its mean; $h$ is the time, necessary for the production of insulin in $\beta$-cells of the pancreas. $r_{I}>0$ characterizes the linear rate of production of insulin; $r_{G}>0$ shows the linear growth in the blood the level of sugar; with the help of parameters $a$ and $b$ a feedback is realized. Parameter $a$ controls the rate of insulin production, parameter $b$ regulates the level of sugar in blood.

Research shows a sufficiently good agreement between the results of the model and the experimental date [6].

The functionality of rising sugar level in blood related to admittance of food, i.e. functionality of alimentary hyper-glycemia, still is not ascertained. Certain results of clinical experiments show that regime of nutriment can "synchronize" the dynamics of sugar level in blood [7], in such a way concealing the individual biorithm of sugar level in blood. Alimentary hyper-glycemia is sufficiently vividly process, which occurs as an influence of certain periodic external force on sugar in the blood system. Therefore it is necessary to take into account the regime of nutriment. For model (1.1) - (1.2) this is done in [8] in the following way:

$$
\begin{aligned}
& \dot{I}(t)=r_{1}\left\{\frac{G(t)}{K_{G}}+a\left[1-\frac{G(t)}{K_{G}}\right]-\frac{I(t-h)}{K_{I}}\right\} I(t), \\
& \dot{G}(t)=r_{G}\left\{1+g(t)+b\left[1-\frac{I(t)}{K_{I}}\right]-\frac{G(t)}{K_{G}}\right\} G(t) .
\end{aligned}
$$


Here the piecewise linear function $g(t)=g(t+24)$ reflects the dietary regime.

The analysis carried out by qualitative and numerical methods, comparison of the obtained theoretical curves with the experimental data, as well as with the other clinical findings allow us to conclude, that the model (1.3) (1.4) explains the functioning of the physiological system "insulin - sugar" in normal and pathological cases, i.e., diabetes mellitus and hyperinsulinism and fits for various regimes of nutriment.

\section{THE PROBLEM OF EXOGENOUS INSULIN INPUT}

Natural access of insulin into the blood is a periodical process, which is regulated by feedback. When this mechanism is disturbed (in case of diabetes mellitus), introduction of insulin adequate to introduction of sugar is applied. Periodical hypodermic injections can simulate by "insulin stock", which can ensure access of the insulin into the blood for some time.

Therapy of insulin-dependent diabetes mellitus (IDDM) can by fulfilled only with the help of insulin based drugs. In clinical practice insulin group medicaments fall under three groups according to the action time: short, medium, long.

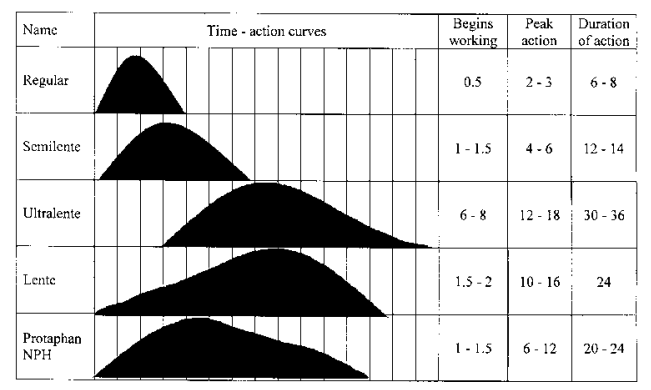

Figure 1.

Fig.1 Presents the time-action curves and fundamental characteristics of the available insulin. NPH (neutral protomine hagedorn), Lente and Regular comprise the three basic insulin, and we could manage without the others. Semi-Lente is acting slightly longer than Regular and Ultra-Lente is very

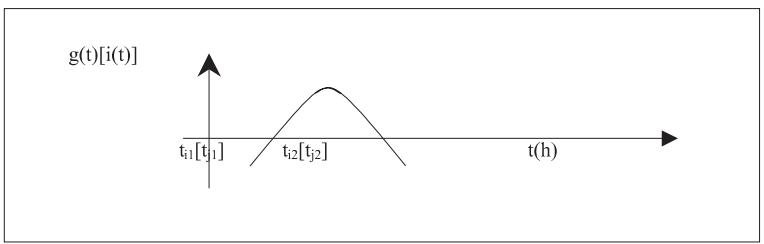

Figure 2. 
long-action insulin. It is impossible to define the amount of the deficiency insulin and to calculate the necessary amount to a particular patient. Usually it is done empirically and it is defined according to the life-stile, stereotype of nutrition, physical activity, sensitivity to exogenous insulin etc. In the past it used to be a general practice to introduce the fall dose of long and short action insulin once in 24 hours. At present a combination of various insulin preparations is injection in strict correlation to periods of post-alimentary hyperglycemia.

A necessity to develop the control methods of the blood sugar level in patients with diabetes mellitus is indisputable. Let $i(t)=i(t+24)$ be a function, reflecting the effect of injected insulin on the dynamics of the blood sugar level. It is proposed to introduce the control into the model in the following way:

$$
\begin{aligned}
& \dot{I}(t)=r_{1}\left\{\frac{G(t)}{K_{G}}+a\left[1-\frac{G(t)}{K_{G}}\right]+i(t)-\frac{I(t-h)}{K_{I}}\right\} I(t), \\
& \dot{G}(t)=r_{G}\left\{1+g(t)+b\left[1-\frac{I(t)}{K_{I}}\right]-i(t)-\frac{G(t)}{K_{G}}\right\} G(t) .
\end{aligned}
$$

Considering that the maximal effect corresponds to maximal rate access of exogenous glucose and insulin to the blood functions $g(t)$ and $i(t)$ can be illustrated as in fig. 2.

If $n$ is the number of meals time and $m$ is the number of injections, then

$$
g(t)=g(t+24)=\sum_{i=1}^{n} g_{i}, \quad i(t)=i(t+24)=\sum_{j=1}^{m} i_{j}(t),
$$

here

$$
\begin{aligned}
& g_{i}(t)=g_{i}(t+24)=\alpha_{i} \sin \left[\frac{\pi}{T_{i}}\left(t-t_{i 1}\right)\right], \quad t_{i 1} \leq t \leq t_{i 2}, \\
& i_{j}(t)=i_{j}(t+24)=\beta_{j} \sin \left[\frac{\pi}{T_{j}}\left(t-t_{j 1}\right)\right], \quad t_{j 1} \leq t \leq t_{j 2},
\end{aligned}
$$

here $\alpha_{i}, \beta_{i}$ are parameters. There are no general methods for solving the system of nonlinear delay differential equations, like (2.1) - (2.2). A linear and nonlinear analysis $(2.1)-(2.2)$ was carried in [8], where it was assumed that $g(t)=0$ and $i(t)=0$. The values of parameters quantitatively describing the concrete patients can be taken like this

$$
K_{I}=15 ; K_{G}=170 ; r_{G}=21 ; h=4 ; b=0.34 .
$$

The part of $D$-partition of plane $r_{I} a$ is presented on 3. 4 shows the solution of system (2.1) - (2.2) in the case of parameters (2.5) and

$$
r_{I}=0.54, \quad a=0.2 .
$$




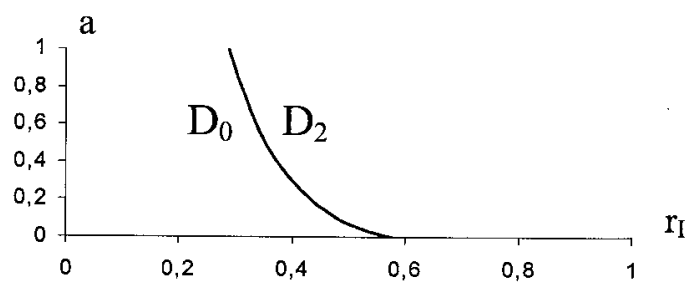

Figure 3.

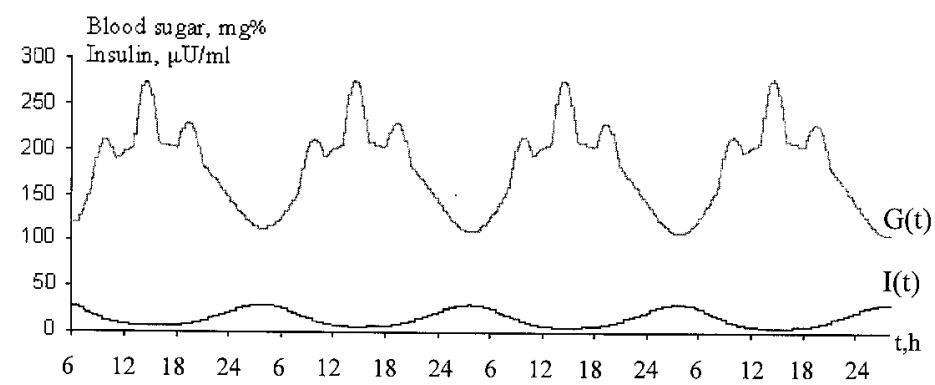

Figure 4. Only meals without introduction of insulin. Breakfast -8.00 a.m., lunch - 1p.m., supper - 6p.m.

The investigation of the model was carried out numerically witch $i(t)=0$ and $n=3, T_{i}=3$

$$
\begin{aligned}
& t_{11}=8, \quad t_{12}=11, \quad \alpha_{1}=0.2 \quad \text { (breakfast) } \\
& t_{21}=13, \quad t_{22}=16, \quad \alpha_{2}=0.4 \quad \text { (lunch) } \\
& t_{31}=18, \quad t_{3} 2=21, \quad \alpha_{3}=0.2 \quad \text { (supper) }
\end{aligned}
$$

In this model various regimes of insulinotherapy given in literature $[9,10,11]$ were tested. fig. 5 - fig. 9 show profiles of the level of glycemia and insulin. The parameters $(2.5),(2.6),(2.7$ were ) related to one particular patient. For example in the case of fig. 5 .

$$
\begin{array}{llll}
m=3 & t_{11}=7 & t_{12}=13 & \beta_{1}=2 \\
T_{j}=6 & t_{21}=12 & t_{22}=18 & \beta_{2}=3 \\
& t_{31}=17 & t_{32}=23 & \beta_{3}=1
\end{array}
$$

The obtained results show a significant decrease of the glycemia level and stability of periodical solutions, they enable us to conclude that the model is adequate to real situations and allows to choose the course of treatment of IDDM. 


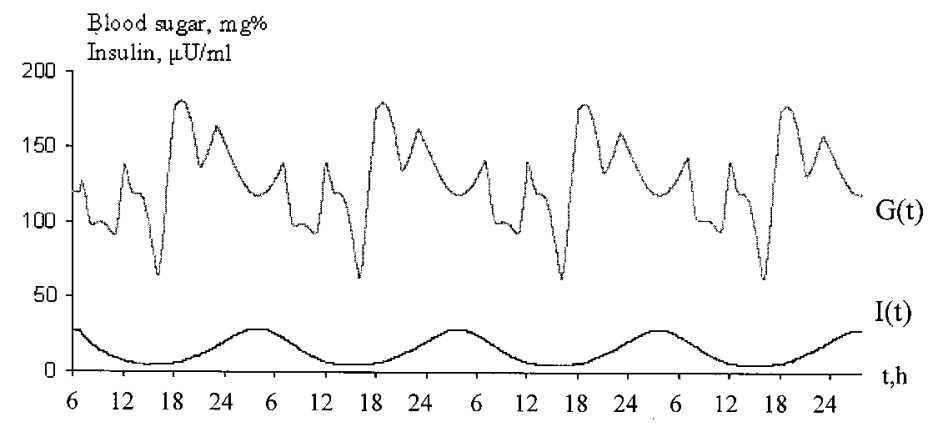

Figure 5. Regular insulin injected 3 times before a meal.

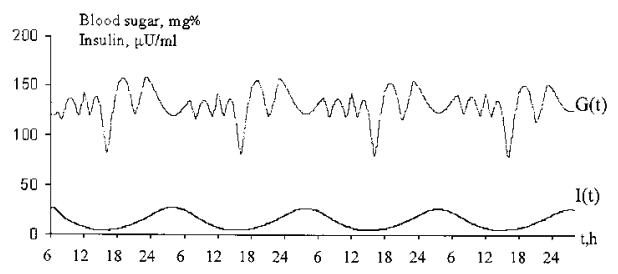

Figure 6. In the morning injection Lente insulin and Regular insulin injected 3 times before a meal.

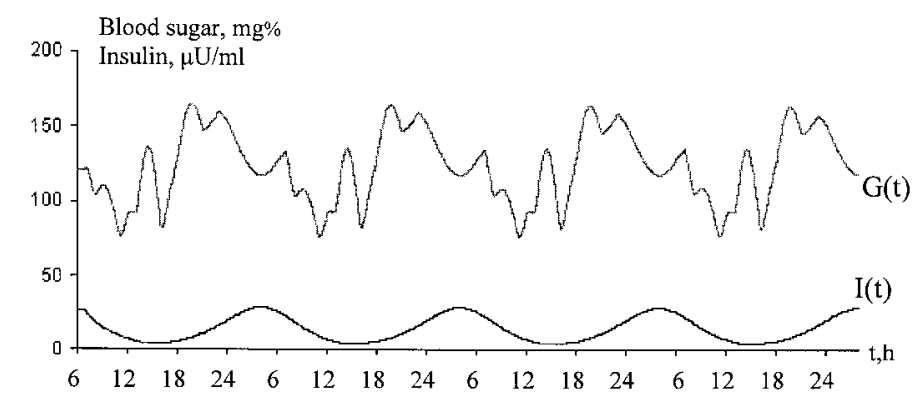

Figure 7. Before a breakfast Lente, Semilente and Regular insulin, before supper injected Regular insulin 


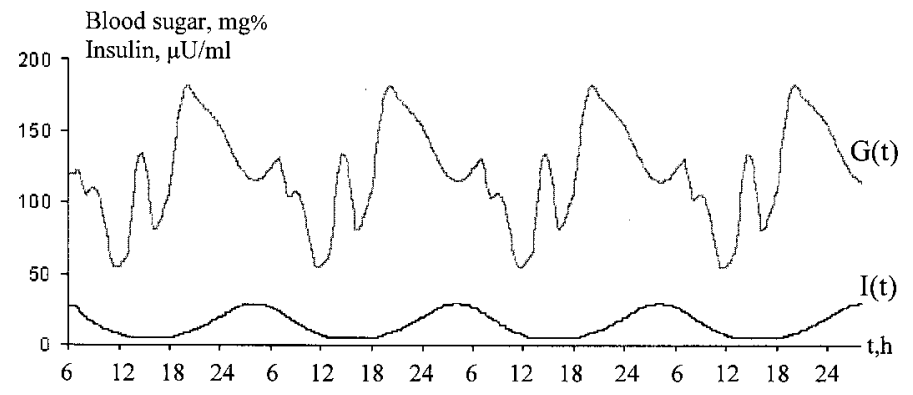

Figure 8. In the morning Lente, Semilente and Regular insulin.

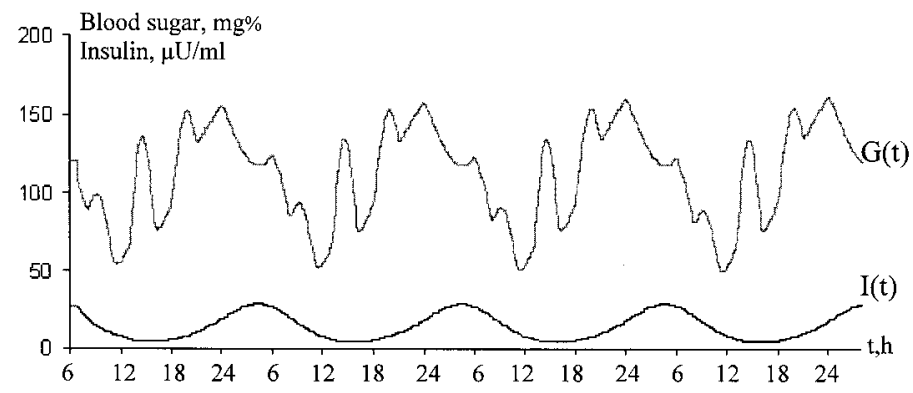

Figure 9. In the morning Semilente, Ultralente and Regular insulin. 
It is evident that when insulin is given twice or even 3 times a day, it prevents significant oscillation of sugar level in blood from normal or hypoglycemia to hyperglycemia.

\section{REFERENCES}

[1] L.G. Leibson. Sahar krovi. AN SSSR, Moskva-Leningrad, 1962. (in Russian)

[2] D.I. Švitra. Dinamika fiziologicheskih sistem. Vremia, Moskva, 1989. (in Russian)

[3] V.W. Bolie. Coefficients of normal blood glucose regulation. J.Appl.Physiol., 16, 1961.

[4] C. Malherbe, M. De Garparo, R. De Hertogh and J.J. Moet. Circadians variations of blood sugar and plasma insulin level in man. Diabetologija, 1969.

[5] G.Y.Nicolau et al.. Circadian variations in plasma immunoreactive (IRI) and C-peptide concentrations in adult onset (type II) Diabetes Mellitus. Rev. Roum. Med. (Endecrinol), 1984.

[6] D. Švitra. Sudètingụ biologiniụ sistemụ dinamika. In: XXXVII Lietuvos matematiku draugijos konferencija darbai. Kaunas, 1996.

[7] J. Mallerstrom and H. Sollberger. Fundamental concepts underlying the metabolic periodicity in diabetes. Arn. N.Y. Acad.Sci, 58 (4), 1962.

[8] I. Basov and D. Švitra. Glycemia monitoring. Nonlinear Analysis: Modelling and Control, 2, Vilnius, 1998.

[9] A.G. Mazoveckij and V.K. Velikov. Saharnii diabet. Medicina, Moskva, 1987. (in Russian)

[10] E.P. Kasatkina. Saharnii diabet u detei. Medicina, Moskva, 1990.

[11] J.S. Skyler, D.L. Skyler, D.E. Seigler at all. Algorithms for Adjustment of Insulin Dosage by Patients Who Monitor Blood Glucose. Diabetes Care, 4 (2), 1981.

\section{GLIKEMIJOS MONITORINGAS: INSULINO IVEDIMO UŽDAVINYS}

\section{BASOV, M. MEILŪNAS, D. ŠVITRA}

Darbe nagrinejjamas cukraus kiekio kraujyje savireguliacijos matematinis modelis. Jis aprašomas dviejų netiesinių diferencialinių-skirtumų lygčių su vèluojančiu argumentu sistema. Nagrinëjama konkrečiu pacientu glikemijos savireguliacijos sistema. Matematinis modelis leidžia nustatyti insulino doze ir režimą, kai naudojame tradicinę insulino terapiją. Pateikti skaičiavimų rezultatai, iliustruojantys kelis ligos ir maitinimosi režimus. 